\title{
Psykopatiproblemer fra behandlingssynspunkt
}

\author{
Af GEORG K. STÜRUP* ${ }^{\star}$ )
}

Psykopatiproblemerne kan anskues fra mange synsvinkler og tager sig forskelligt ud, fra hvilken vinkel man ser dem. Teoretisk-abstrakt kan de analyseres på basis af en kortere tids kontakter med hver især af en række påfaldende personer og en teoretisk bearbejdning af det iagttagne. Det ligger måske i vor tids videnskabelige m $\varnothing$ nster at interessere sig mere for analysen, detaljen, end for helheden, syntesen, og derfor er det nok ikke så mærkeligt, at den videnskabelige litteratur har beskæftiget sig mere med diagnostiske end med fortsatte forl $\varnothing$ bsbilled-analyser.

Psykopater er lige så lidt som neurotikere syge mennesker. Det er personer med fra det normale gennemsnitlige afvigende reaktionsberedskab. De skal således ikke kureres, men have mulighed for at udvikle egne muligheder. Man har i fortiden talt om psykopatisk degeneration, men viger nu tilbage for en så grov moralistisk betegnelse. Vi kan heller ikke længere tillade os at tro på, at de medfødte anlæg eller de tidligt erhvervede egenskaber er af så afgørende betydning, som tidligere antaget, for udviklingen af den personlighedsstruktur, man har kaldt psykopatisk. Udtrykket degeneration udskiftedes først med konstitution, så med personlighed. Når konstitution bruges i betydningen: den samlede helhed af individets nedarvede og erhvervede stabile egenskaber, dækker det udtrykket personlighed. Med Schneider (1955) er jeg enig i, at man ikke har en psykopati så lidt som man har en neurose - man er psykopat, resp. neurotiker.

Udfra mere lægmandsmæssige betragtninger er der en vis tilb $\varnothing$ jelighed til at se psykopatierne som en slags småpsykotiske tilstande eller forl $\phi$ bere herfor. Schneider (1955) mener (s. 45), at jurister er tilbøjelige hertil.

Reaktionsberedskab er et vagt og ikke særlig godt begreb. I praksis kan dette bestemmes via adfærdsanalysen og dens aktuelle relation til det situationsbestemte.

Udfra sociologiske synspunkter har Shoham (1967) nylig kritiseret det kliniske psykopatibegreb. Han opstiller en række fænomenologiske almindeligt anvendte kriterier på psykopatisk adfærd :

*) Foredrag holdt i Dansk Kriminalistforening 9. december 1968. 
1. Mangel på samvittighed.

2. Manglende konsekvent livsplan.

3. Manglende mulighed for kærlighed eller binding til medmennesker. Psykopaten har kun venner, som han onsker at udnytte til egne formål.

4. Psykopaten er $\varnothing$ jebliksorienteret, forsåvidt som han som udtryk for sine aktuelle $\phi$ nsker mangler evne til at forskyde denne dyrkelse af det $\phi$ jeblikkelige til fordel for mere langsigtede kulturelle mål.

5. Et resultat af hans stadige frustration og $\varnothing$ jebliksorientering er sammenst $\varnothing \mathrm{d}$ med samfundets normative strukturer, og dette $f \varnothing r e r$ igen til aggressioner.

Ved en systematisk gennemgang af nutidens vestlige kulturmønster finder Shoham, at disse beskrivelser passer på alt for mange almindelige mennesker. En definition, der bygger på elementer som disse, finder Shoham derfor ikke af praktisk interesse.

Omvendt har det efter min opfattelse vist sig muligt at bistå såkaldte psykopater på en måde, så deres medmenneskelige samspil forbedres, altså således at det igangværende samfundsmæssige forkastelige adfærdsm $\emptyset$ nster ændres. I en række tilfælde har det været muligt at behandle de ,ubehandlelige“ og dermed bryde den triste, selvforstærkende ring eller i visse tilfælde spiral.

Omkring 30erne, da straffeloven trådte i kraft, var Schneiders synspunkter ved at trænge igennem i Danmark. Schneider en ledende tysk psykiater - var ganske klar over, at psykopatibegrebet var et rent praktisk begreb. Blandt de abnorme personligheder afgrænsede han, udfra en samfundsmæssig værdinorm, psykopaterne - de psykopatiske personligheder — som dem, der på grund af denne personlighedsabnormitet bliver til ulempe for sig selv eller for samfundet, altså i væsentlig grad afgrænset på samme måde som i straffelovens § 17.

Ved en diskussion i Psykiatrisk Selskab i februar 1968 understregede Vanggård med rette, at afgrænsningen af abnorme personligheder fra en gennemsnitsnorm heller ikke er værdifri. Men det gælder jo også afgrænsningen af andre tilstandsbilleder, som f. ex. åndssvaghed, der også er et fænomenologisk begreb, der har vist sig praktisk brugbart.

Som forsvar for forsфget på at genoplive psykopatidebatten har Vanggård talt om behovet for at bringe orden i fænomenverdenen. Jeg er enig i, at dette er en af diagnostikkens opgaver og tilstrækkelig i samspillet med juraen. Retspsykiatrisk kan begrebet godt anvendes. Som lægeligt begreb b $\phi \mathbf{r}$ der i en diagnose også ligge noget af en anvisning til andre fagfolk om, hvilken 
behandlingsform der herefter må sk $\phi$ nnes optimal, og den b $\phi r$ forhåbentlig også sige fagmanden noget om sandsynlig ætiologi og prognose. Udtrykket psykopati siger mig intet i disse lægelige henseender.

At gå ind i en efter min opfattelse steril debat om psykopatibegrebet, der nu i Danmark mest bruges som skældsord, har jeg ikke lyst til, men jeg har aldrig benægtet, at psykopater og neurotikere frembyder store forskelle, omend der indbyrdes dem imellem er grænsetilfælde, der vel er hovedårsagen til de diagnostiske uenigheder. I stedet vil jeg prøve rent praktisk at undersфge en gruppe af de personer, psykiatere og domstole i fællesskab har fundet karakterologisk utilstrækkeligt udrustede i forhold til de problemer, de stăr overfor, her og nu, og egnede til anbringelse i den institution, der etableredes ved den nye straffelovs ikrafttræden, - dengang betegnet som psykopatanstalten. Fordelen herved er, at man i de forløbne år har haft lejlighed til iagttagelser af det fortsatte forl $\varnothing \mathrm{b}$ og kan konkludere, at det imod forventningerne - ikke i almindelighed er tilstande, der ikke kan behandles. Lægeligt har det vist sig at være en broget forsamling, uden mange fællestræk.

Den danske lov har den enestående fordel, at den ikke rummer medicinsk diagnostiske begreber. ${ }^{\star}$ )

Retten har lige så lidt brug for at vide, hvilke årsager der er til åndssvaghed som til „,psykopati“. Insufficiensen, beskrevet i præmisserne i jævne ord, er fuldt tilstrækkelig for ikke-lægelige myndigheder.

Man taler i $\S 17$ i den danske straffelov om mennesker, som ikke er sindssyge eller åndssvage, men som dog på grund af deres varigere forstyrrelse eller svækkelse af sjælsevnerne er anderledes end gennemsnittet og anderledes i så $h \phi j$ grad, at de derigennem frembyder en større fare for retssikkerheden end gennemsnitspersonen. Disse gode og jævne beskrivende udtryk har medf $\phi \mathbf{r t}$, at vi fortrinsvis får de tilfælde, der danner kernegruppen af psykopater, uanset hvilken psykopatidefinition, der anvendes (Stürup, 1950).

De forvarede er i hvert fald i langt de fleste tilfælde ,psykopater", eller karakterinsufficiente, som jeg har foretrukket at kalde de samme personer. Kun yderst få ville det fra et behandlingsmæssigt synspunkt være rimeligt at placere noget andet sted

*) Ikke alle lande er så heldige. En af de seneste autoritative definitioner er lovfæstet så sent som i 1959 i den engelske Mental Health Act. Denne lov afgrænser:

"A persistant disorder and disability of mind (whether or not including subnormality of intelligence) which results in abnormally aggressive or seriously irresponsible conduct on the part of the patient and requires or is receptible to medical treatment". 
i vort reaktionssystem. Særfængslet skal jeg ikke omtale her. Udvælgelsen hertil er for tilfældig. En stor del af dem, vi har fået, er forvaringsemner, andre har intet specielt behov for vor behandling, atter andre kan vort behandlingssystem utvivlsomt hjælpe. (Den gruppe, der under afsoningen i statsfængsel eller arbejdshus viser sig for påfaldende og derfor overføres til fængselsvæsenets psykiatriske observationsafdeling i Herstedvester, er i langt højere grad velanbragt hos os. Dette forhold taler til gunst for i fremtiden, at fængselsvæsenet selv — og ikke domstolene - foretager sorteringen til psykiatrisk særbehandling af fanger, ganske som etaten selv sorterer til åben eller lukket anstalt (Waaben, 1968, pp. 140 og 154)).

Straffeloven blev skabt og trådte i kraft i en tidsperiode, hvor man i længere tid havde koncentreret sig om at udøve retfærdighed ved at lægge den afg $\phi$ rende vægt på de aktuelle kriminelle handlinger, som man havde vejet - ikke altid på guldvægt hvorfor man dengang tænkte sig muligheden af at sætte mennesket i centrum, ikke den konstaterede handling. Den kongelige anordning, der fortsat er gældende for behandlingen i forvaringsanstalterne, stiller følgende opgave i $\S 2$ : at sikre samfundet imod de farer for retssikkerheden, som personer, der forvares i anstalten, på fri fod ville frembyde, og indenfor de derved dragne grænser at underkaste de indsatte en efter deres sjælelige særart afpasset behandling, således at de bliver egnet til at vende tilbage til det frie liv.

Omend tankerne bagved var længere tids forvaring som det primære overfor de ,ubehandlelige“, stilledes hermed også en socialpsykiatrisk opgave. I nogle få årtier har vi hermed i Danmark haft mulighed for rent klinisk at koncentrere interessen om en udvalgt gruppe af kriminelle mennesker. Som udgangspunkt tog man en gruppe personer, om hvem domsmyndighederne bestemte, at de havde været til tilstrækkelig forulempning for samfundet, således at man kunne betegne dem som farlige for retssikkerheden, men gjorde det således, at man også kunne - og burde - tage hensyn til personen selv. Vi har i Herstedvester ment at varetage hans interesser ved $\mathbf{i}$ nogen grad at se bort fra de aktuelle handlinger og i stedet rette søgelyset mod de betingelser, der havde medf $\varnothing \mathrm{rt}$ og måske fortsat ville medf $\phi \mathrm{re}$ kriminalitet $\mathrm{i}$ form af tilbagevendende gentagelser af kriminelle forhold af ikke ubetydelig karakter. Udfra dette synspunkt kan vi ikke undgå at se de psykopatiske handlinger som "symptomer" eller måske udtryk for symptomer.

Det har været et i penologiens historie ret enestående experiment, idet det har fået lejlighed til at løbe i så lang tid. Philadelphia-systemet, Maconochios arbejde i Australien, irlænderen Croftons system, varede hver især ganske få år (Torsten Eriks- 
son, 1967). Vi har haft betydelig medvind og anerkendelse. Der er nu tegn til, at vurderingen af vort arbejde er ved at svinge. Dette kan ikke være på grundlag af en undersøgelse af dette arbejde, for en sådan er ikke foretaget. Vort retssystem er måske ved at vende tilbage til den omtalte mere klassiske, såkaldte retfærdighed, hvor det fortrinsvis — eller måske kun — er den seneste kriminalitets art og st $\varnothing \mathrm{rrelse}$, der danner grundlag for rettens vurdering. I alle tilfælde er vilkårene for vort rehabiliteringsarbejde i de seneste år — særlig overfor berigerne — blevet forringet stærkt, og derfor er der rimelighed i at g $\phi$ re status. $\mathrm{F} \phi \mathrm{r}$ denne motivation blev aktuel, har jeg beskrevet vort arbejde langt udf $\phi$ rligere, end jeg kan g $\varnothing$ re det i dette foredrag. Det skete i mine to første Isaac Ray forelæsninger, holdt i Philadelphia for $\check{a}$ år siden. De er nu for nogle måneder siden udkommet under titlen: Treating the "Untreatable" Chronic Criminals at Herstedvester, Denmark. På John Hopkins forlag, Baltimore. Den specielle danske behandling af visse sexualkriminelle er også udkommet som den 3. Isaac Ray forelæsning hos Munksgaard under titlen: Treatment of Sexual Offenders in Herstedvester, Denmark.

Af andres erfaringer skal særligt henvises til de hollandske. Lederen af van der Hooven Klinikken i Utrecht, Anna Marie Rosenburg, gav under det meget instruktive CIBA symposium i London 1967 udtryk for fuld enighed med os i Herstedvester om værdien af den ubestemte tid og bekræftede en del af de forskelle og ligheder i behandlingsapparatet, som Conrad har beskrevet.

Vort klientel, psykopater eller hvad de ellers kaldes, afviger i meget udtalt grad fra det almindelige med hensyn til mellemmenneskelige samspil. Det er meget påfaldende, $\mathrm{i}$ hvor $\mathrm{h} \phi \mathrm{j}$ grad de betragter sig selv som udst $\varnothing$ dte, og derigennem bliver deres relationer til almindelige borgere også ændret. Disse i forhold til kriminaliteten sekundære reaktioner er vigtige som udgangspunkt for psykoterapien.

Et andet karakteristikum er, at de har vist meget ringe stabilitet i deres reaktionsm $\varnothing$ nstre. Det, vi med et ikke skarpt afgrænset ord kalder holdningsløshed, dominerer i mange tilfælde. I sit februar-foredrag talte Vanggård om den forvarede, som „, blikkelig slår den person ned, der i sin stillings medf $\phi \mathbf{r}$ overbringer ham myndighedernes afslag på en ans $\varnothing$ gning om pr $\varnothing v e l \varnothing s-$ ladelse ...". Efter vor erfaring er det uhyre sjældent at træffe en person med et sådant reaktionsm $\varnothing$ nster, som noget blot nogenlunde karakteristisk. Med en passende optræden fra personalets side og med det samspilsmønster, der kan udbygges $\mathrm{i}$ en institution, er det en sjældenhed. Denne erfaring har ført os til at medinddrage de sociale samspil i alle vore overvejelser. Vi må arbejde med langt mere komplicerede begreber. Først må vi se på 
tilgængelige psykiske resourcer

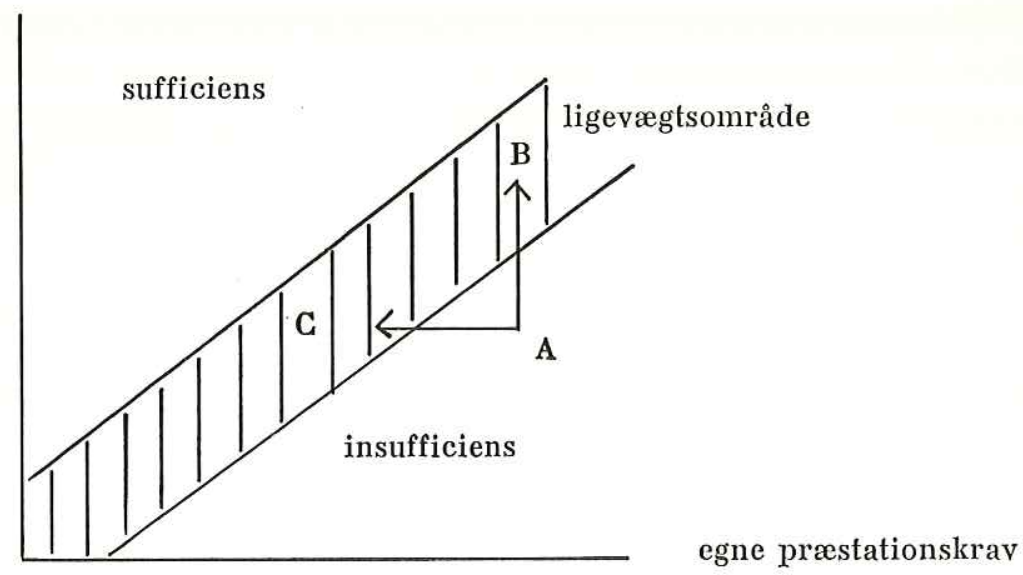

Fig. 1. Skema ad insufficiensoplevelse.

spillet mellem egne psykiske præstationskrav i forhold til de tilgængelige åndelige resourcer (Stürup, 1965 og 1968).

Har vi en person A, kan vi bistå ham til at komme ud af sin insufficienstilstand ved at bedre hans tilgængelige psykiske resourcer, f. ex. behandle en evt. læsevanskelighed eller ordblindhed, og bringe ham til B, eller evt. højere op. Eller vi får ham til at dæmpe sine krav, d. v. s. bringer ham til position C. Eller vi kan gøre begge dele.

Skæbnetro og forvanskning af medmenneskers forventning til ham hører til de stadigt tilbagevendende temaer for vore forvarede. Derved bliver disse forhold til væsentlige problemer i behandlingsarbejdet. Jeg har kaldt dette den dobbelte forventning. I et mellemmenneskeligt samspil, det vi kalder relationen mellem 2 personer A og B, optræder den oplevede A og den af ham selv oplevede B, men dertil kommer A's oplevelse af B, og B's oplevelse af A, og endelig A's oplevelse af B's oplevelse af ham selv (A), såvel som A's oplevelse af B's opfattelse af B. Udnyttes vor viden om dette spil på fornuftig vis, risikerer man i almindelighed ikke reaktioner, som de af Vanggård i februar-foredraget, se NTfK 1968 side 300 forventede. Men selvf $\phi$ lgelig sker der uheld, også alvorlige.

Den måde, vi perciperer - d. v. s. oplever og sanser — os selv og andre i mellemmenneskelige situationer, er også betinget af den aktuelle emotionelle modenhedstilstand, men især har vi iagttaget, at talrige reaktionsm $\varnothing$ nstre af endda særdeles stabil 
karakter utvivlsomt er betinget af den kriminelle situation og denne situations følger. Dette gælder ikke mindst den følelsesmæssige indsnævring, næsten afstumpethed, der jævnligt kan iagttages hos de personer, der overrumples af at have begået en meget alvorlig kriminel handling. Der går ofte år, f $\varnothing \mathbf{r}$ dette „f $\varnothing$ lelseskolde" forsvarsapparat bryder sammen, således at man derefter kan se den bagvedliggende overf $\varnothing$ lsomhed.

En af vore vigtigste opgaver er at modvirke det tab af selvrespekt, der er en af f $\varnothing$ lgerne af det kriminelle liv og den dertil knyttede doms- og fængselsmæssige behandling, og ikke at forglemme den evt. omtale i massemedierne. Med en st $\varnothing$ rre selvrespekt skulle den forvarede få større mulighed for at percipere mellemmenneskelige situationer på en måde, der er i større harmoni med almindelige menneskers perceptioner. Det er for denne proces væsentligt, at den forvarede selv oplever, at han kan få kontakt ikke alene med den psykoterapeutisk arbejdende læge, men også med det almindelige personale. Det er også n $\emptyset$ dvendigt for indsatte og ansatte nu og da at se, at et og andet lykkes, at have succes, ikke alene og ikke specielt $\phi$ konomisk, socialt, men således at man oplever, at man trods en fortid fuld af skuffelser kan gennemf $\varnothing$ re realistiske planer.

Selv kriminologer (Jepsen, 1968) kan give udtryk for, at ,de indsattes næsten indædte kritik af den så humane danske kriminalforsorg“" er almindelig, og rejse spørgsmålet, om human indstilling og små institutioner, beskæftigelse til alle m. v., er nok. Det er det selvfølgelig ikke, men den ,indædte kritik“ serveres også f $\varnothing$ rst og fremmest til dem, der venter den og måske bliver skuffet, om den ikke kommer. Vi, der år ud og år ind følger den enkeltes udvikling, således som den sætter sig spor i de mellemmenneskelige relationer - ikke alene overfor medforvarede, men sandelig også overfor personalet og terapeuten - og som i gruppeterapim $\varnothing \mathrm{der}$ har set den enkeltes fortvivlelse og skuffelser, forstår godt, at reaktionen hos en del af dem, der ikke kommer ud over skuffelserne over sig selv, må blive en eller anden form for forsvar, herunder også ,indædt kritik“. Det er jo svært at konstatere fiasko gang efter gang, når man — og det gælder også langt de fleste af vore forvarede - helst ville slippe ud af sin kriminelle karriere.

På basis af betragtninger af den karakter, jeg nu ganske kort har omtalt, kalder vi vor arbejdsform for den individualiserede integrerende vækstbehandling. En af de vigtigste medarbejdere - om ikke den vigtigste - er manden selv. Vi s $\varnothing$ ger at motivere ham til at tro på, at han kan skifte kurs. Dernæst s $\varnothing$ ger vi at etablere et samspil mellem adæquate sikkerhedsforanstaltninger, psykoterapi, somatisk terapi, undervisning og rehabiliteringsarbejde og socialmedicinsk st $\varnothing$ tte i prøvetiden. 
Et af de vigtigste midler til koordinering er den daglige konference. Her udvikles hos akademiske og ikke-akademiske deltagere en f $\phi$ lelse af samh $\phi$ righed. Den relative værdi af de enkelte medarbejderes professionelle indsats kan herunder lettere vurderes af de andre og tildels af hver især selv. Et andet element, der har stor erfaringsmæssig betydning er kontinuiteten i kontakten med den indsatte. Kun derigennem ser vi tilstandsbilleder skifte og diagnoser begynder at vakle. I mange tilfælde begynder ændringer i adfærd med en udvikling af nerv $\varnothing$ se symptomer. Der optræder let depressive reaktioner og forstemninger, såvel som psykosomatiske klager. Vi har hidtil kaldt det en neurotisering og set det som et stadie på vej til en mere symptomfri tilværelse. Interessen for aktiv indsats i psykoterapien stimuleres $i$ hvert fald $i$ en sådan fase.

Siden Stephen Taylor i 1949 skrev om The Psychopath in Our Midst. A Danish Solution, har vi haft bes $\phi g$ af mange penologisk interesserede. Der er skrevet meget venligt om os, og diskussionerne med sådanne bes $\varnothing$ gende har været meget stimulerende. Noget af den vigtigste kritik, der er blevet rettet i de udenlandske arbejder, der har fors $\phi g t$ at analysere vor situation, er, at vi i så ringe grad har været $\mathrm{i}$ stand til at bearbejde det enorme erfaringsmateriale, der er samlet i vore journaler. Vi må håbe på, at en senere generation videref $\phi \mathrm{rer}$ arbejdet med videnskabelig kontrol. Interessen for sådanne fors $\phi \mathrm{g}$ er stor i flere lande - på begge sider af jerntæppet.

Noget væsentligt er allerede nu opnået. Den massiveste del af den traditionelle pessimisme er brudt, og man er begyndt at experimentere. Det gælder både de mere teoretiske forhold som den reelle betydning af at være afviger inden for en eller anden gruppe (Freedman and Doob, 1968) og rent praktisk gennemf $\phi \mathrm{rte}$ behandlingsfors $\phi \mathrm{g}$. Eksempelvvis arbejdes med placering af „forvarede“, psykotiske og psykopatiske, så de tvinges til et koncentreret debatpræget samliv uden formildende omstændigheder fortsat d $\varnothing$ gnet rundt i ugevis, månedsvis. En form for gruppeterapi der er uh $\phi$ rt belastende. De f $\phi$ rste forel $\phi$ bige beretninger er ved at indl $\phi$ be fra Canadas endnu vistnok mest avancerede institution i Penetangfishine. Med st $\varnothing$ tte fra Ford-Foundation har Bradley og medarbejdere (1968) udarbejdet detaillerede planer for kontinuerlig gruppevis behandling af unge kriminelle. Det forudsættes, at samme stab til stadighed er til rådighed både i perioden indenfor og udenfor, og i nært samarbejde med familien. Først efter intensiv-perioden er slut, kommer der fritid til personalet, og så er der opsparet adskillige måneders frihed.

Herhjemme har der ikke været megen offentligt st $\phi$ ttet behandlingsforskning. Korttidsfange-unders $\phi$ gelsen i Vestre fængsel er vist den eneste. Lysten til at eksperimentere er på disse 
felter ikke stor. På grundlag af arbejdet i Herstedvester gav FordFoundation en meget stor bevilling til et kontrolleret behandlingsexperiment overfor ungdomskriminalitet, der påbegyndtes på Nørrebro i 1960. De videnskabelige kontrolanalyser er endnu ikke færdige, så der kan forel $\varnothing$ big kun siges, at der sikkert rejses flere spфrgsmål, end der gives svar.

I den senere tid er der herhjemmefra særlig rejst kritik af anvendelsen af forvaring overfor berigelseskriminelle. Det postuleres, at de forvaredes manglende kendskab til frihedsber $\varnothing$ velsens længde er en for stor psykisk belastning i forhold til dens behandlingsmæssige fordel, og der tales også om et uheldigt afhængighedsforhold til ledelsen, der skal give indstilling om udskrivning. Ingen af disse to postulater har mig bekendt rod i andet end abstrakte spekulationer og har i hvert fald ikke været unders $\phi$ gt i Herstedvester. Indtil fornylig har vi ikke spildt megen tid på diskussion af det tidsubestemte, men sammenblandingen med særfængselsfanger synes at sætte gang i drillerierne overfor forvarede. Dette $\mathrm{i}$ forbindelse med den genoplivede accentuering af takstsystemer og nogle meget særprægede forsvareres udfald med kraftig pressest $\varnothing$ tte, indbygger hos de forvarede forestillinger om at være uretfærdigt $\mathrm{d} \phi \mathrm{mt}$. Til Waabens tvivl om forvarings effektivitet $b \phi r$ tilf $\varnothing j$ es, at den endnu ikke er belyst på videnskabelig forsvarlig vis (Waaben, 1968, p. 108).

Ikke for at tilfredsstille de videnskabelige krav, men for at danne mig et indtryk af vore resultater overfor denne gruppe, har jeg forel $\phi$ big analyseret 10 års forl $\phi b$ for et antal umiddelbart efter hinanden modtagne berigelseskriminelle (røveri, tyveri, bedrageri, underslæb m. m.).

Dette materiale er mere kursorisk omtalt i Treatment bogen, men prakfiske vanskeligheder førte til en utilfredsstillende grafisk fremstilling.

Materialet indsamledes i 1966, og er derfor d $\varnothing \mathrm{mt}$ i 1956, 1955 og 1954, - samtlige berigere i ubrudt række. Tabellarisk drejer det sig om:

6 eufomane, hvoraf 3 recidiverede kriminelt, og en af disse var atter i forvaring på 10 års dagen. Yderligere udskiltes 5 , der var eller under opholdet blev sindssyge.

Tilbage var 83 personer med relativt ren berigelseskriminalitet. 44 var alkoholiserede i større eller mindre grad (B + alkohol), 39 havde ingen alkoholproblemer (B).

De enkelte forl $\phi b$ vil fremgå af fig. 2-7. Nederst i hvert billede ses de mange tidligere interneringsperioder - de tynde streger - fra nulpunktet forvaringstiderne for hver enkelt person, fulgt i 10 år efter første dom til forvaring — de brede sorte bånd. 


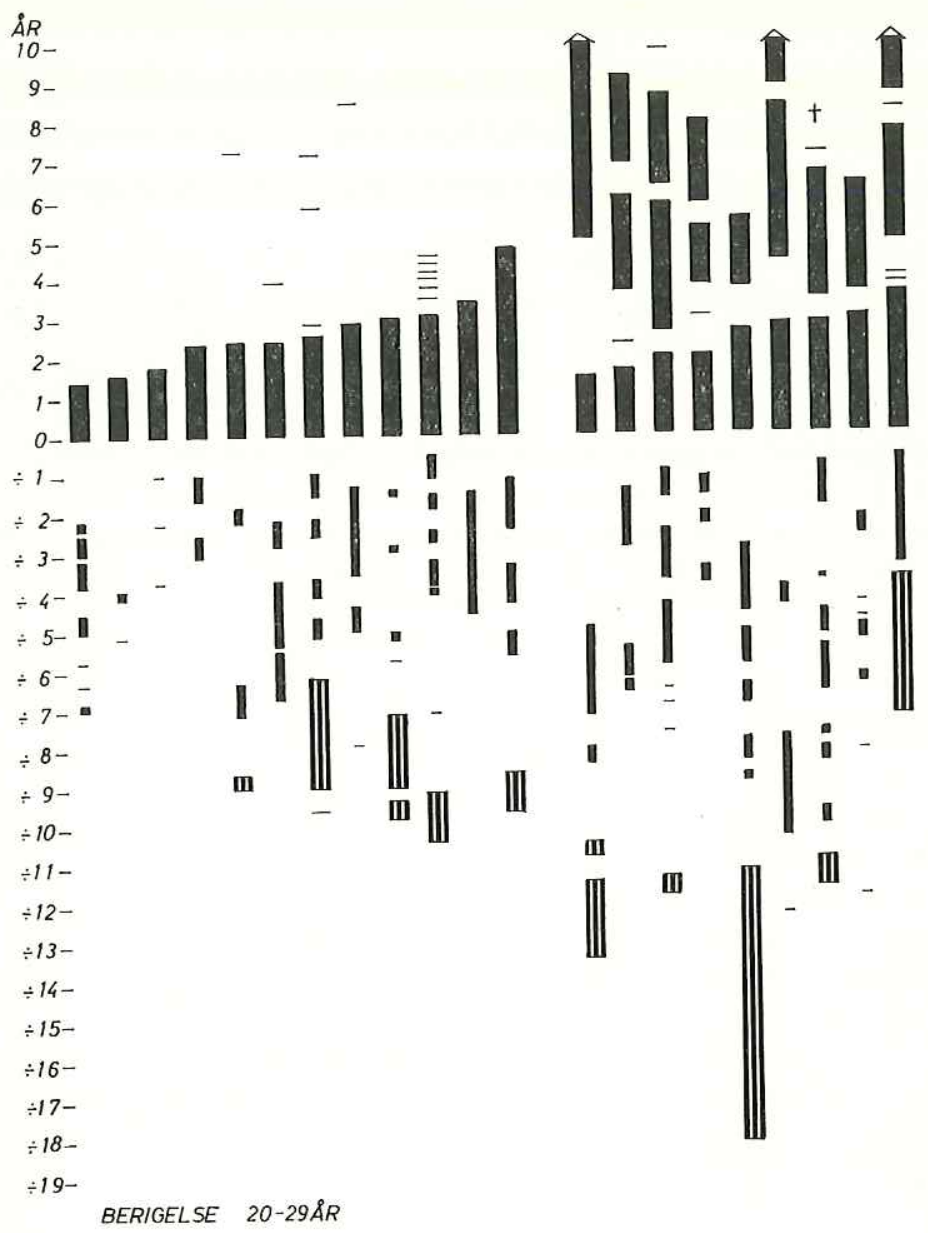

Fig. 2.

I dette og de f $\phi$ lgende diagrammer svarer 0-punktet til f $\phi$ rste indlæggelse i forvaring (1956. - 55 eller -54$)$.

De brede stribede bånd nederst $\mathrm{i}$ billedet angiver anbringelse $\mathrm{i}$ institutioner under opvæksten, i b $\varnothing$ rne- og ungdomsforsorgen.

De ikke recidiverede står længst til venstre og er ordnet efter forvaringsopholdets længde. Derefter følger de recidiverede, ordnede på tilsvarende måde. 


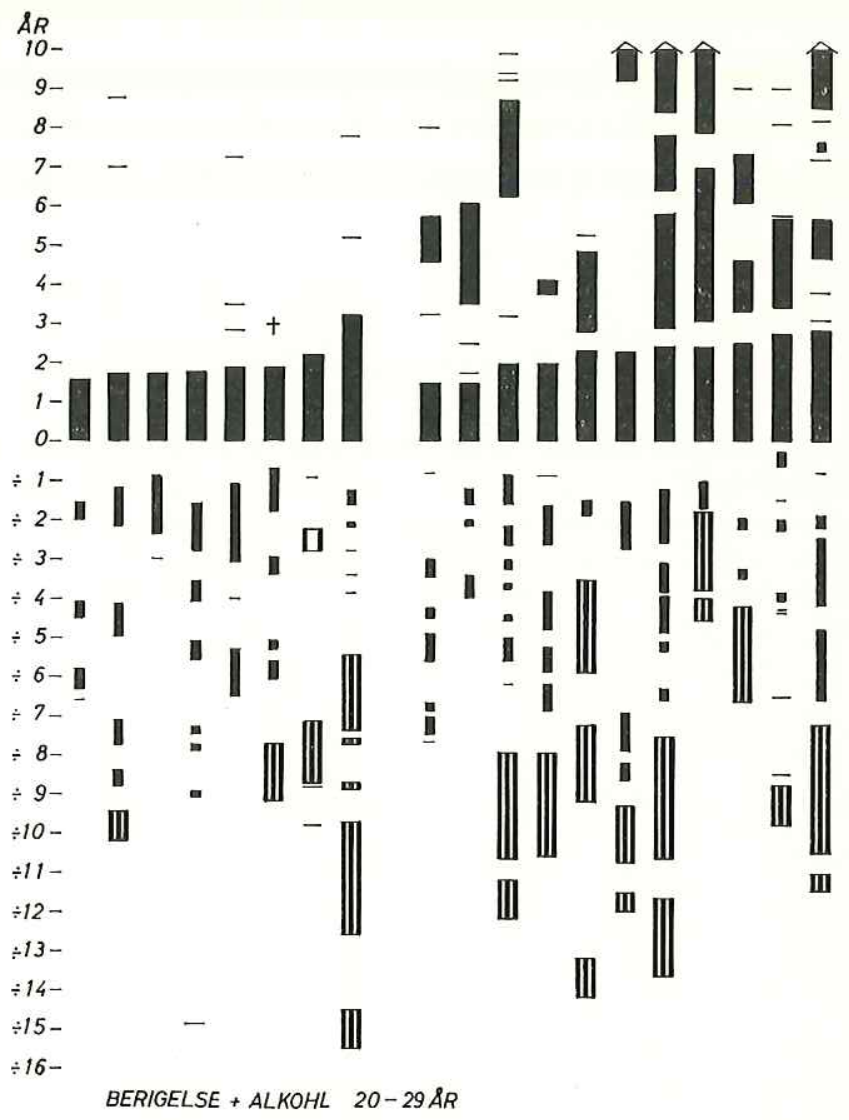

Fig. 3. 


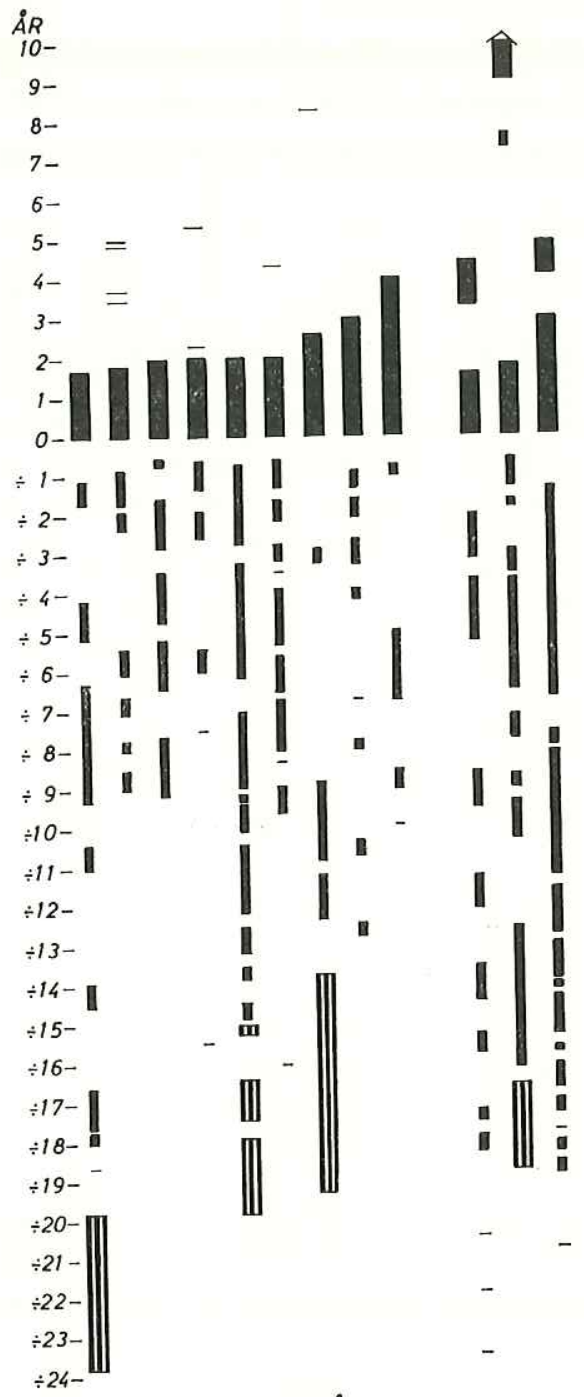

BERIGELSE $30-39 A R$

Fig. 4. 


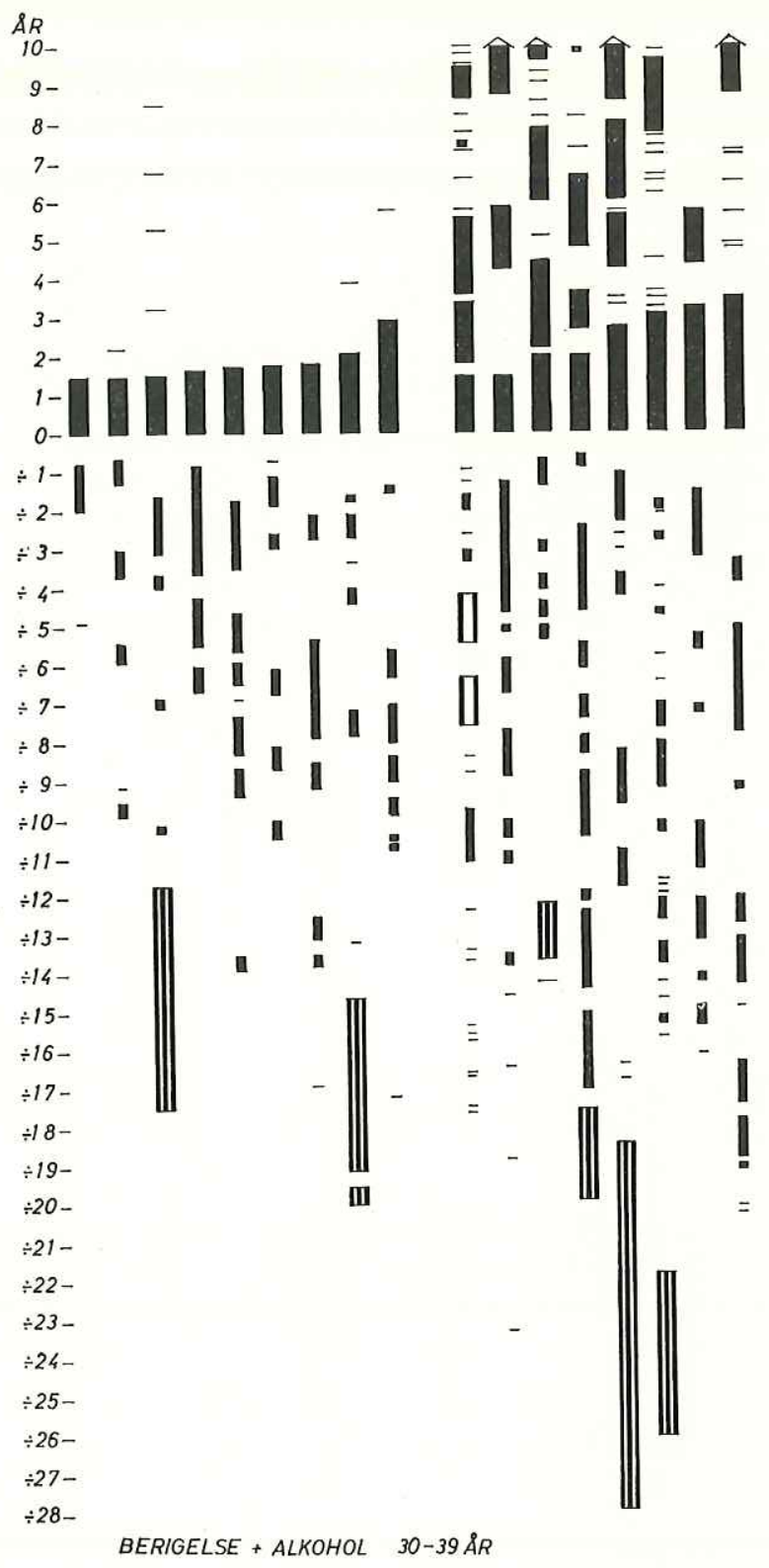

Fig. 5. 


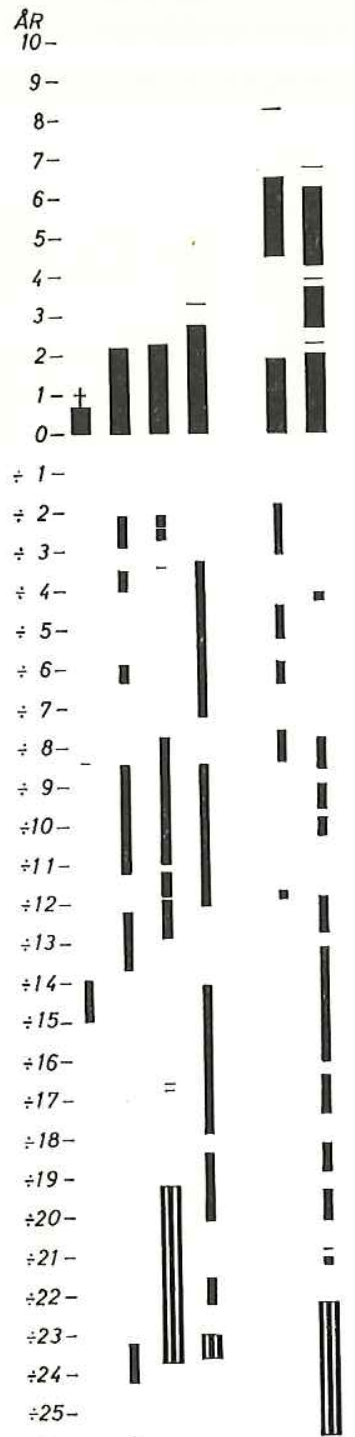

$\AA R$

$10-$

$9-$

句

$7-$

6-

$5-$

4--

3-
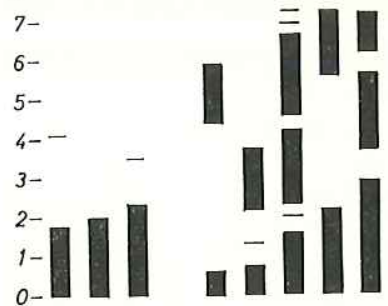

$\div 1-$ n

$\div 2-$
$\div 3-$
$\div 4-$
$\div 5-$
$\div 6-$
$\div 7-$

$\div 8-$

$\div 9-$

$\div 10-$

$\div 11-$

$\div 12-$

$\div 13-$
$\div 14-$
$\div 15-$
$\div 16-$
$\div 17-$
$\div 18-$
$\div 19-$

$\div 20$ -

$\div 21-$

$\div 22-$

$\div 24-1$

$\div 25-\quad$ - III

$\div 27-$ -

$\div 28-$

$\div 29-$

$\div 30-$

$\|=-\| 1$

$\div 26-\quad$ 目

$\div 27$ -

$\div 31-$

$\div 28$ -

$\div 32-$

$\div 29-\quad=$

$\div 33-$

$\div 31-$
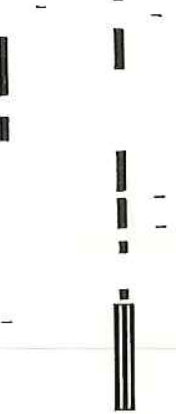


$$
\text { 20-29 år: } \quad 30-39 \text { år: } 40 \text { år og derover: }
$$

rene B: 21, heraf rec. 912 , heraf rec. 3 6, heraf rec. 2 Af de 39 :

$\begin{array}{lllllll}\mathrm{B}+\text { alk.: } 19-1117-8-8-5 & \begin{array}{l}36 \% \text { rec. } \\ \text { Af de } 44: \\ 55 \% \text { rec. }\end{array}\end{array}$

Ialt 40, heraf rec. 2029 , heraf rec. 11 14, heraf rec. 7 Af de 83: $=50 \%=38 \% \quad=50 \%$ $46 \%$ rec.

$$
\begin{aligned}
& 7=15 \% \text { år efter dommen fandtes i forvaring: } \\
&
\end{aligned}
$$

De små pilespidser — ialt 13 foroven på forvaringssøjlerne markerer, at pågældende ved 10-årsdagen for første indlæggelse i forvaring fortsat er i anstalten. De enkelte streger betyder kortvarig tilbageholdelse p. gr. af enten ganske lille kriminalitet eller en sigtelse, der ikke blev opretholdt.

Af disse levnedsforl $\phi \mathrm{b}$ ses klart, at det drejer sig om et meget belastet materiale. Det skal klart understreges, at disse billeder vel viser, at mange resocialiseres, men intet beviser om effektiviteten af vor behandling. De siger klart, at den traditionelle håbløshedsvurdering af disse stærkt belastede er absolut forkert.

Hvad der mangler, er selvfølgelig belysning af en lang række forhold, f $\varnothing$ rst og fremmest en analyse af, hvordan disse mennesker lever nu i forhold til f $\varnothing \mathbf{r}$ forvaringen. Hvorledes er deres sociale status f $\phi \mathrm{r}$ og efter, og hvorledes er deres psykiske tilfredshedstilstand?

Selvom det skulle vise sig, at resultaterne ikke svarer til bekostningen, det arbejdet har kostet staten, og det den enkelte indlagte har ydet $\mathrm{i}$ afsavn og tårer, står een ting dog fast: den mere individualiserede behandling, disse berigelseskriminelle har været undergivet, er i sig selv mere humanitært hensigtsmæssig end den stadigt og $n \varnothing$ dvendigvis standardiserede fængselsbehandling. Meget af det, vi har fors $\varnothing \mathrm{gt}$, har kunnet indpasses i det almindelige fængselsarbejde, og afstandene mellem f. ex. leveforholdene i vore åbne fængsler og forvaringens åbne afdelinger er stadig blevet mindre.

Det store flertal af dem, der har været $\mathrm{i}$ stand til at leve en kriminalitetsfri tilværelse, har været dybt taknemmelige og har givet udtryk for det, når man har mødt dem, f. ex. i Tivoli, på Bakken eller simpelthen på gaden. Det er gentagne gange hændt, at en

*) Da aggressions- og sexualkriminelle har mindre recidiv, er det almindeligt angivne 10 -ârs tilbageværende $10 \%$ fortsat rigtigt. 
bil er standset, fordi føreren ville hilse på og forklare, hvor godt det går ham, men også for at berette, hvor store problemer, der gang efter gang er dukket op på arbejdspladserne i tilslutning til omtale af kriminelle forhold, - hvordan befolkningens holdning $\mathrm{i}$ almindelighed langt fra er forstående, og meget ofte bærer præg af den klassiske aggressionsholdning overfor de udst $\varnothing \mathrm{dte}$. Denne holdning vil næppe ændres forel $\phi$ big. Den upersonligg $\phi-$ relse, som samfundet har gennemgået med tilb $\varnothing$ jelighed til at lægge vægt på adfærdsstandardisering, har ikke været nogen hjælp. På urealistisk sentimental vis at prise den stakkels undertrykte fange lige så ivrigt nedvurdere de pligtopfyldende tjenestemænd, der yder en samfundsmæssigt nødvendig indsats i fængselsarbejdet, går jo kun for en tid. Reaktionen venter lige om hjørnet. Skal vi nă til en realistisk forbedring af den jævne borgers holdning overfor tidligere kriminelle, vil en st $\varnothing$ rre interesse for ofrenes skæbne sikkert være nyttig. Vi trænger til en bedre offentlig service til ofrene for de kriminelle handlinger, ikke mindst ofrene for voldshandlinger. Her vil det være af betydning, at hjælpen falder hurtigt og uden hensyn til, om gerningsmanden er fundet eller ej. Sygekassens dagpenge og den evt. invalidepension er ikke tilstrækkelig til at afb $\varnothing$ de f $\varnothing$ lgerne af det samfundsonde, kriminelle handlinger repræsenterer.

Til slut skal det understreges, at jeg er fuldt ud klar over, at vi ikke har fundet noget Columbus-æg. Vi står ved begyndelsen af en udforskning af kriminelle personers adfærd og af dennes komplicerede årsager. Psykopatiklassificering er kun en tom navngivning og siger $h \varnothing j$ st lidt om et af årsagsforholdene til den kroniske kriminalitet. Fundet af en enorm overvægt af en speciel kromosomabnormitet (xyy) blandt legemligt høje, aggressionsprægede kriminelle er måske indledningen til fornyet interesse for de biologiske baggrundsfaktorer hos kronisk kriminelle. Der er også social-psykologiske baggrundsfaktorer. Via en ændring af opvækstbetingelser og leveforhold vil vi måske kunne begrænse det antal tilfælde, der går ind i den voksne verden præget af sjælelige ardannelser. St $\varnothing$ rre kendskab til følgerne af de psykiske sår, der opstår hos kronisk kriminelle kan måske f $\phi$ re til, at også de senere ardannelser begrænses. Den kriminelles personlighedsmæssige adfærdsm $\varnothing$ nster beh $\phi$ ver næppe oprindeligt at have været særlig forskelligt fra det, der betinger de ikke pågrebne borgeres færd. Det store antal personer, der har begået uopdaget kriminalitet, tyder på, at en væsentlig del af den ofte fremhævede kriminelle særart er et sekundært fænomen. Socialpsykologiske forhold, der $\mathrm{g} \phi \mathrm{r}$ opdagelsen af kriminel adfærd lettere, er måske af stor betydning.

Måske kan vi via intensivering af studierne over kriminelles leveforhold og spec. de kronisk kriminelles livsm $\phi$ nstre i deres 
samspil med andre mennesker nå til at se på hele området udfra epidemiologiske synsvinkler. De behandlingsfors $\varnothing$ g, der nu er igang flere steder i verden, vil måske få særlig betydning herigennem, men dette forudsætter, at videnskabeligt orienterede medarbejdere dukker op, og at man ikke slår sig til ro med skrivebordsmæssige overvejelser om de kriminelles ulykkelige livsforl $\phi \mathrm{b}$ som en samfundsmæssig n $\varnothing$ dvendighed for os andre.

Georg K. Stürup

\section{LITTERATUR}

Bradley, Harold B. et al.: Design for Change. A program for Correctional Management. Institute for the Study of Crime and Delinquency. Sacramento, California. 492 p. 1968. Funded by the Ford Foundation. Manuskript.

Conrad, John: Crime and its Correction. 1965. University of California Press. Berkeley and Los Angeles.

Eriksson, Torsten: Kriminalvård 1967. Nordstedt och Söners. Stockholm.

Freedman, Jonatan and A. N. Doob: Deviancy. 1968. Academic Press. N. Y. and London.

Jepsen, Jørgen: Anmeldelse af Joseph Conrad: Crime and Correction. Nordisk Tidsskrift for Kriminalvidenskab, 1968, p. 271.

Nielsen, Johs., T. Tsuboi, G. Stürup, D. Romano: XYY Chromosomal Constitution in Criminal Psychopaths. 1968. The Lancet, p. 576.

Rosenburg, A. M. i de Reuck, A. V. S. and Ruth Porter: The Mentally Abnormal Offender. 1968. J. \& A. Churchill. London, p. 173.

Schneider, Kurt: Klinische Psychopathologie. 1955. Georg Thieme Verlag.

Shoham, Shlomo: Psychopathy as social Stigma. A Myth Revisited. 1967. Corrective Psychiatry and Journal of Social Therapy, vol. 13, p. 21.

Stürup, Georg K.: Psykopatibegrebet. En historisk oversigt. 1950. Ugeskrift f. Læger, vol. 112, p. 35-39.

Stürup, Georg K.: A Situational Approach to Behavioural Disorders. 1965. Proceedings of the Leeds Symposium on Behaviour Disorders. May \& Baker. London.

Stürup, Georg K.: Treating the "Untreatable" Chronic Criminals at Herstedvester, Denmark. 1968. Johns Hopkins Press. Baltimore.

Stürup, Georg K.: Treatment of Sexual Offenders in Herstedvester, Denmark. 1968. Munksgaard, København.

Taylor, Stephen: The Psychopath in our Midst. A Danish Solution. 1949. The Lancet, p. 32.

Waaben, Knud: Utilregnelighed og særbehandling. 1968. Festskrift udgivet af K $\phi$ benhavns Universitet. 